\title{
KEAMANAN BATASAN DATA MENGGUNAKAN METODE WRITE VALIDATION DALAM DISTRIBUTED DATABASE SYSTEM
}

\author{
Untung Rahardja ${ }^{1}$ \\ Hidayati $^{2}$ \\ Reny Ardyanti ${ }^{3}$ \\ E-mail: untung.rahardja@faculty.raharja.ac.id, hidayati@faculty.raharja.ac.id, \\ renyardyanti@si.raharja.ac.id
}

Diterima :22 Juni 2010/Disetujui : 18 Agustus 2010

\begin{abstract}
Along with the advancement in information technology and the rapid rate of development encourages the development of distributed databases. The objective application of webbased information system that is so that users can access information anywhere and anytime. However, increasing numbers of data, making the system take a long time in doing the data display. To handle made of a display buffer which we call by the term Data Mart Queries (DMQ). However, it turns out DMQ any constraints which have the data will not be updated so that the displayed data is not realtime data, while data is always changing all the time in different user and client. For that needed a new solution through the write method of validation. Although the data is not updated display data, but with this method should make the process of validation system first, before his execution on the run. In this article, identified two problems in a distributed system, especially a problem in displaying the data view to users quickly, yet remain secure when executed, write the definition of validation, validation write three characteristics, advantages and disadvantages of write validation, algorithm and benefit from this method. On implementation, the displayed listing program written using ASP script. Contribute to the write method of validation in a distributed database system is a solution which is helpful to keep the time of the execution of database security, although the data shown is the data buffer that is used to maintain the standard TWT (tolerable Wait Time).
\end{abstract}

1. Dosen Jurusan Sistem Informasi, STMIK Raharja

Jl. Jend. Sudirman No. 40 Cikokol - Tangerang Telp. 5529692

2. Mahasiswa Jurusan Sistem Informasi, STMIK Raharja

Jl. Jend. Sudirman No. 40 Cikokol - Tangerang Telp. 5529692

3. Mahasiswa Jurusan Sistem Informasi, STMIK Raharja

J1. Jend. Sudirman No. 40 Cikokol - Tangerang Telp. 5529692 


\section{ABSTRAKSI}

Seiring dengan kemajuan teknologi informasi dan laju perkembangannya yang semakin pesat mendorong adanya perkembangan distributed database. Tujuan diterapkannya sistem informasi berbasis web yaitu agar user dapat mengakses informasi dimanapun dan kapanpun. Namun, semakin bertambahnya data, membuat sistem membutuhkan waktu lama dalam melakukan display data. Untuk menanganinya dibuatlah sebuah buffer display yang biasa kita sebut dengan istilah Data Mart Query (DMQ). Namun, ternyata DMQ tersebut pun mempunyai kendala yaitu data menjadi tidak update sehingga data yang ditampilkan bukanlah data realtime, sementara data selalu berubah setiap saat diberbagai user dan client. Untuk itu diperlukan sebuah solusi baru melalui metode write validation. Walaupun display data bukanlah data update, namun dengan metode ini sistem harus melakukan proses validation terlebih dahulu, sebelum eksekusi dijalankan. Dalam artikel ini, diindentifikasi 2 masalah yang dihadapi dalam suatu sistem terdistribusi khususnya masalah dalam menampilkan view data ke pengguna dengan cepat, namun tetap aman saat dieksekusi, definisi dari write validation, 3 ciri khas write validation, keuntungan dan kelemahan dari write validation, algoritma serta manfaat dari metode ini. Pada implementasinya, ditampilkan listing program yang ditulis menggunakan script ASP. Kontribusi metode write validation dalam distributed database system merupakan suatu solusi yang sangat membantu menjaga keamanan database saat dilakukan eksekusi, walaupun data yang ditampilkan merupakan data buffer yang digunakan demi menjaga standard TWT (Tolerable Wait Time).

Kata kunci : write validation, DMQ (Data mart Query), TWT (Tolerable Wait Time)

\section{PENDAHULUAN}

Perkembangan teknologi yang terus meningkat dengan pesat, mempengaruhi laju kebutuhan manusia atas informasi, terlebih disuatu organisasi atau perusahaan. Informasi terus mengalir dan jumlahnya semakin lama semakin meningkat seiring dengan jumlah permintaan, serta jumlah data yang semakin banyak, sehingga membuat sistem membutuhkan waktu lama dalam melakukan display data. Selain itu penggunaan database dalam suatu perusahaan dan organisasipun menjadi semakin kompleks terlebih dengan adanya sistem jaringan. Database dapat didistribusikan dari satu komputer ke komputer lain, sehingga jumlah arus pemakaipun meningkat.

Organisasi maupun perusahaan membutuhkan sistem informasi untuk mengumpulkan, mengolah dan menyimpan data serta mendistribusikan suatu Vol.4 No.1 - September 2010 
informasi. Berkembangnya sistem informasi dari waktu ke waktu telah menghasilkan banyak informasi yang semakin kompleks. Kompleksnya informasi tersebut disebabkan oleh banyaknya permintaan, serta meningkatnya jumlah data dan tingkat iterasi perintah display data dalam suatu sistem informasi.

Pemanfaatan teknologi informasi oleh organisasi atau perusahaan secara garis besar bertujuan untuk memudahkan pelaksanaan proses bisnis dan meningkatkan kemampuan kompetitif. Melalui teknologi informasi, diharapkan proses bisnis perusahaan dapat dilaksanakan lebih mudah, cepat, efektif dan efisien. Penggunaan teknologi jaringan didalam suatu organisasi, perguruan tinggi ataupun perusahaan merupakan hal yang biasa di era globalisasi seperti sekarang ini. Didalam suatu sistem jaringan banyak organisasi ataupun perusahaan yang telah menerapkan database terdistribusi, namun semakin bertambahnya data sehingga menimbulkan masalah ketidaknyamanan khususnya perihal respon time agak lama dalam melakukan display data tersebut.

Menurut penelitian yang dilakukan oleh Hoxmeier \& DiCesare pada tahun 2000, bahwa waktu respon halaman web adalah metrik paling sederhana yang mengukur kepuasan pengguna. Tapi saat ini bandwidth dan pengalaman pengguna telah meningkat, pedoman untuk respon halaman web pun telah berevolusi. Menurut Schneiderman yang didirikan pada tahun 1980, bahwa 15 detik adalah waktu menunggu ditoleransi. Menurut King, bahwa untuk dapat muncul sebagai Internet dan Web di tahun 1990-an, waktu tanggapan toleransi dibagi menjadi 2, yaitu 8 12 detik tanpa umpan balik, dan 20 - 30 detik atau lebih dengan umpan balik. Pada tahun 1996 Jacob Nielsen pun menulis bahwa 10 detik adalah waktu respon maksimum sebelum pengguna kehilangan bunga. Zona Riset menerbitkan sebuah studi yang sering dikutip untuk Akamai yang menawarkan aturan 8 detik. Pada awal 2003, King menemukan bahwa rata-rata TWT (Tolerable Wait Time) adalah 8,6 detik untuk kondisi sekarang.

Untuk menjaga kepuasan pelanggan dalam mengakses sistem informasi, digunakanlah cara pembuatan sebuah buffer display yang biasa disebut dengan Data Mart Query (DMQ). DMQ ini akan membantu user dengan cepat melakukan display data, karena data tidak perlu lagi diproses, namun data hanya di display. Karena sifatnya yang seperti buffer, maka DMQ ini mempunyai kelemahan yaitu data yang ditampilkan adalah data hasil buffer, bukanlah data real time. Sehingga dapat juga dikatakan bahwa data tersebut tidak update. Apalagi jika data tersebut adalah data yang selalu berubah setiap saat diberbagai client. Untuk itu diperlukan 
sebuah metode untuk menangani masalah ini, namun tetap memperhitungkan kepuasan pelanggan dari segi TWT (Tolerable Wait Time).

\section{PERMASALAHAN}

Distributed database memang memiliki banyak keunggulan terlebih untuk struktur organisasi saat ini. Namun diantara keunggulan itu, distributed database juga memungkinkan suatu sistem menjadi lebih kompleks, karena banyaknya database yang tersebar dan terus meningkatnya jumlah data didalam suatu organisasi maupun perusahaan. Jika suatu database memiliki sejumlah data yang tersimpan dengan banyak query dan tabel, suatu permintaan mengakibatkan proses pencarian data atau source data menjadi lambat. Selain itu banyaknya user dan client yang dapat mengakses suatu sistem informasi juga menjadi salah satu faktor penghambatnya. Seperti hal nya yang terjadi pada O-OJRS (Otomatisasi Online Jadwal Rencana Study), integritas datanya membuat sistem tersebut melakukan proses lebih lambat.

Didunia perguruan tinggi, KRS adalah salah satu fokus utama agenda setiap semester. Bukan hanya bagi pihak manajemen, namun juga menjadi kebutuhan utama para mahasiswa. Berkembangnya teknologi informasi memaksa kita untuk dapat mengikuti arus tersebut, dan memanfaatkan perkembangannya dalam hal penyusunan Otomatisasi Jadwal Rencana Study (OJRS) serta pendistribusiannya yang dilakukan secara online. Tidak berhenti sampai disini, perkembangan teknologi pun menuntut kita agar proses pergantian mata kuliah, yang biasa disebut dengan istilah batal tambah, dapat dilakukan oleh mahasiswa baik secara mandiri maupun online.

Untuk menyatakan bahwa batal tambah online siap untuk diimplementasikan, itu tidaklah mudah. Banyak hal yang harus ditesting terlebih dahulu. Banyaknya kelas yang dibuka, banyaknya user yang mengakses, banyaknya data yang difilter, dan banyaknya client, semua itu mempengaruhi proses testing tersebut. Hanya sekedar untuk mengakses daftar kelas yang dibuka, setiap user membutuhkan waktu kurang lebih 20 detik untuk memprosesnya. Hal ini tidak sesuai dengan teori response time yang menyatakan bahwa TWT (Tolerable Wait Time) standar adalah 8.6 detik. Untuk itu dinyatakan bahwa lambatnya proses bukan hanya disebabkan banyaknya data, namun juga dikarenakan banyaknya proses filterisasi.

Filterisasi untuk daftar kelas yang dibuka yaitu bahwa data yang di display adalah seluruh kelas yang sesuai dengan id kurikulum, yang sesuai dengan shift yang diambil (siang/malam), yang belum lulus, belum ada di KST semester aktif dan KST semester lalu, status jadwalnya tidak bentrok, populasi mahasiswa tidak melebihi quota kelas, serta prasyarat mata kuliah pun sudah memenuhi(sudah lulus). 
Untuk mengatasi masalah diatas dan demi mempertahankan kecepatan proses data digunakanlah konsep Data Mart Query (DMQ). DMQ (Data Mart Query) merupakan konsep yang menerapkan analogi "Waste Space for Speed". Cara kerjanya yaitu melakukan pemisahan antara "Engine" dan "Display". Secara umum DMQ menghasilkan sebuah display data yang jauh lebih cepat dibandingkan dengan sebelumnya, karena DMQ tidak melakukan proses lagi dalam menampilkan data. Akan tetapi dengan memakai DMQ bukan berarti masalah selesai. Terdapat masalahmasalah lainnya yaitu data menjadi tidak update sehingga data yang tampil bukanlah data realtime, sementara data selalu berubah setiap saat diberbagai user dan client. Kronologisnya yaitu,

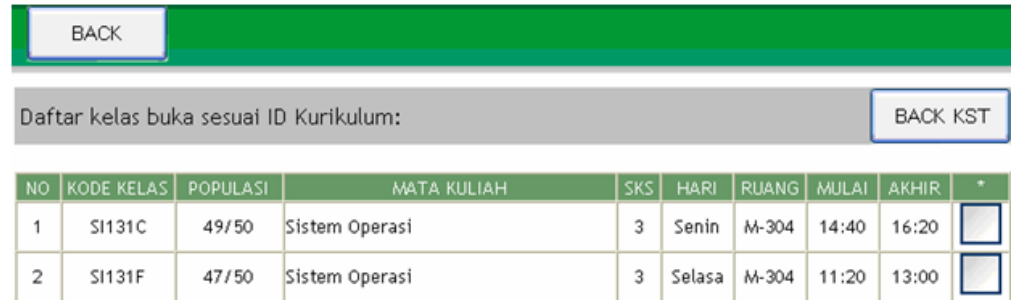

Gambar 1. Daftar kelas buka sesuai ID kurikulum pada O-OJRS tambah kelas

Seperti gambar diatas, saat seorang mahasiswa melakukan proses tambah kelas, dinyatakan bahwa salah satu kelas yaitu SI131C memenuhi syarat. Berarti mahasiswa tersebut berhak untuk menambahkan kelas tersebut pada KST nya. Namun apakah populasi mahasiswanya masih memenuhi syarat quota kelas? Karena mahasiswa lain pun memiliki hak yang sama seperti mahasiswa ini untuk menambahkan kelas SI131C itu pada KST nya diclient lain.

Artinya yaitu antar mahasiswa yang satu dengan mahasiswa yang lainnya saling berlomba untuk dapat terdaftar disetiap kelas. Masalahnya yaitu lebih kepada filterisasi data, bahwa dengan display data yang tidak realtime, dan dengan ada persaingan proses diberbagai user dan client, setiap kelas harus tetap dapat terjaga agar batas quotanya tidak terlewati. Dan tetap dapat filterisasi bahwa kelas yang diambil adalah kelas yang tidak bentrok dengan jadwal KST.

Dari pembahasan diatas, dapat dirumuskan 2 permasalahan yaitu sebagai berikut :

1. Metode apakah yang dapat menjaga keamanan batasan data walaupun data display tidak realtime, sementara data selalu update diberbagai user dan client setiap saat? 
2. Metode apakah yang dapat selalu menjaga standar TWT (Tolerable Wait Time) agar tidak melebihi dari 8,6 detik display data?

\section{LITERATURE REVIEW}

Banyak penelitian yang sebelumnya dilakukan mengenai write validation. Dalam upaya pengembangan display data ini perlu dilakukan studi pustaka sebagai salah satu dari penerapan metode penelitian yang akan dilakukan. Diantaranya adalah mengidentifikasikan kesenjangan (identify gaps), menghindari pembuatan ulang (reinventing the wheel), mengidentifikasikan metode yang pernah dilakukan, meneruskan penelitian sebelumnya, serta mengetahui orang lain yang spesialisasi dan area penelitiannya sama dibidang ini. Beberapa Literature review tersebut adalah sebagai berikut :

1. Penelitian ini dilakukan oleh Nadezhda Filipova dan Filcho Filipov 2008 dari University of Economics. Varna, Bul. Kniaz BorisI berjudul "Development of database for distributed information measurement and control system". Penelitian ini menjelaskan mengenai pengembangan database dari pengukuran informasi yang didistribusikan dan sistem kontrol yang menerapkan metode optik untuk plasma spectroscopy fisika dan penelitian atom collisions dan menyediakan akses untuk mendapat informasi dan sumber daya perangkat keras di jaringan Intranet/Internet, berdasarkan database pada sistem manajemen database Oracle9i. Perangkat lunak klien yang diwujudkan adalah dalam Java Language. Perangkat lunak ini dikembangkan dengan menggunakan model arsitektur, yang memisahkan aplikasi data dari komponen grafis presentasi dan masukan pengolahan logika. Berikut grafis presentasi telah dilaksanakan, pengukuran radiasi dari Spectra beam plasma dan benda, perangsangan fungsi non-elastis collisions dari berat partikel dan analisis data yang diperoleh dalam percobaan sebelumnya. Berikut grafis klien yang memiliki fungsi interaksi dengan database browsing informasi tentang percobaan dari jenis tertentu, pencarian data dengan berbagai kriteria, dan memasukkan informasi tentang validasi percobaan sebelumnya[1].

2. Penelitian yang dilakukan oleh Lieven Desmet, Bart Jacobs, Frank Piessens, Wouter Joosen, 2004, dari Eighth IFIPTC-6 TC-11 Conference on Communications and Multimedia Security (CMS), tentang A Generic Architecture for Web Applications to Support Threat Analysis of Infrastructural Components. Penelitian ini menjelaskan bahwa tentang analisis ancaman yang berguna dari platform aplikasi web, beberapa arsitektur asumsi tentang aplikasi tersebut harus dibuat. Dokumen ini menjelaskan generik khas 
arsitektur aplikasi web. Ini berfungsi sebagai dasar untuk menganalisis ancaman pada infrastruktur yang paling penting komponen dalam arsitektur[2].

3. Penelitian ini dilakukan oleh Jun Lin Lin dan Margaret H. Dunham dari Southerm Methodist University dan Mario A. Nascimento berjudul " A Survey of Distributed Database Checkpointing". Penelitian ini membahas mengenai checkpointing pada database terdistribusi dan pendekatan-pendekatan yang digunakan. Penelitian ini bermula dari adanya banyak survey yang dilakukan berkenaan dengan proses recovery database, dan banyak teknik yang diusulkan untuk mengatasinya. Dengan distributed database checkpointing, dapat mengurangi waktu proses recovery suatu kegagalan didalam database terdistribusi. Checkpointing dapat digambarkan sebagai suatu aktivitas menulis informasi ke penyimpanan yang stabil selama operasi normal dalam rangka mengurangi jumlah pekerjaan pada saat restart. Penelitian ini membantah bahwa sedikit batasan dan sedikit sumber daya menjadi masalah dalam pendekatan database terdistribusi, serta Membantah bahwa checkpointing hanya dapat digunakan untuk sistem distribusi yang multidatabase. Meskipun penelitian ini telah banyak dilakukan namun cukup rumit dalam implementasinya. Dengan penelitian ini kita dapat mengembangkan database terdistribusi dengan checkpointing untuk mempercepat proses recovery database[3].

Penelitian ini dilakukan oleh David J. DeWitt dari Universitas Wisconsin dan Jim Gray tahun 1992 berjudul "Parallel Database Systems:The Future of High Performance Database Processing". Penelitian ini dilakukan dengan konsep database terdistribusi yang merupakan database yang disimpan pada beberapa komputer yang terdistribusi satu sama lain. Pada penelitian ini, dijelaskan Sistem database paralel mulai menggantikan Mainframe komputer besar untuk pengolahan data dan transaksi tugas. Paralel database komputer memiliki arsitektur yang berkembang dari penggunaan perangkat lunak yang eksotik untuk perangkat keras yang paralel. Seperti kebanyakan aplikasi, user menginginkan hardware sistem database yang murah, cepat. Ini menyangkut tentang prosesor, memori dan disk. Akibatnya, konsep hardware database yang eksotis tidak sesuai untuk teknologi saat ini. Di lain sisi, ketersediaan microprocessors cepat, murah dan kecil menjadi paket standar murah tapi cepat sehingga menjadi platform yang ideal untuk sistem database paralel. Stonebraker mengusulkan rancangan sederhana untuk spektrum disain yaitu shared memory, shared disk dan shared nothing. Dan bahasa yang digunakan dalam database adalah SQL sesuai dengan standar ANSI dan ISO. 
Dengan penelitian ini, kita dapat mengembangkan sistem database agar dapat digunakan diberbagai ruang lingkup[4].

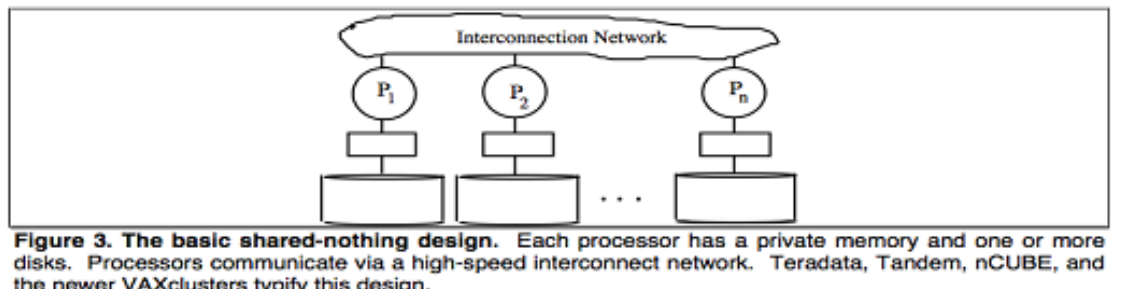
the nower VAXclusters typify this design.

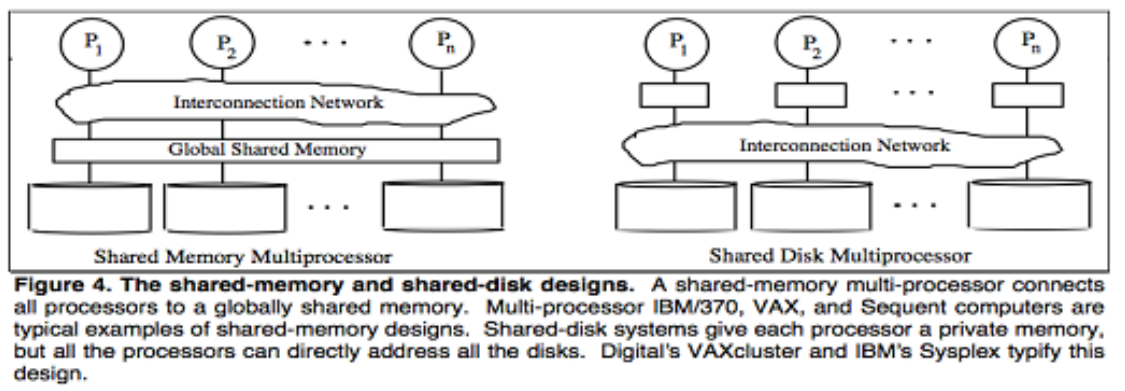

Gambar 2. Desain Shared-Nothing, Shared-Memory dan Shared-Disk

1. Penelitian yang dilakukan oleh Steven P. Coy dari University of Maryland berjudul "Security Implication of the Choice of Distributed Database Management System Model: Relational Vs Object Oriented". Penelitian ini menjelaskan bahwa keamanan data harus dibenahi ketika mengembangkan database dan diantaranya memilih antara relational dan object oriented model. Banyak faktor yang harus dipertimbangkan, terutama dari segi efektifitas dan efisiensi, juga apakah sekuritas dan integritas ini memakan sumber daya yang terlalu besar tidak semata mata fitur keamanan. Kedua pilihan ini akan mempengaruhi kekuatan dan kelemahan dari database tersebut. Untuk centralized database kedua model ini bisa dikatakan sama baiknya. Namun untuk distributed database, relational model lebih unggul dibidang sekuritas. Ini lebih banyak disebabkan karena object oriented model database masih kurang maturitasnya. Sehingga didalam lingkungan heterogenous, proses integritasnya masih menimbulkan banyak masalah. OODBMS tetap saja masih perlu perkembangan teknologi lebih lanjut, namun di lingkungan homogenous, OODBMS dapat menjadi pilihan yang baik[5]. 
2. Penelitian yang dilakukan oleh Stephane Gançarski, Claudia León, Hubert Naacke, Marta Rukoz and Pablo Santini yang berjudul "Integrity Constraint Checking in Distributed Nested Transactions over a Database Cluster" adalah sebuah solusi untuk memeriksa integritas dan kendala global dalam berhubungan multi database sistem. Penelitian ini juga menyajikan hasil eksperimental yang diperoleh atas solusi PC cluster dengan Oracle9i DBMS. Tujuan adalah melakukan eksperimentasi untuk mengukur waktu yang dihabiskan dalam memeriksa kendala global dalam sistem yang terdistribusi. Alhasil menunjukkan bahwa overhead berkurang hingga 50\% dibandingkan dengan pemeriksaan integritas yang terpusat. Studi menunjukkan bahwa sistem berkemungkinan besar melanggar referential integrity dan global conjunctive constraints. Namun dengan cara distributed nested transactions, dengan adanya eksekusi dan parallelism, integritas dapat lebih terjamin[6].

Penelitian yang dilakukan oleh Lubomir Stanchev dari University of Waterloo tahun 2001 berjudul "Semantic Data Control In Distributed Database Environment". Penelitian ini menyatakan bahwa ada tiga tujuan utama dalam semantic data control yaitu: view managemen, data security dan semantic integrity control. Dalam sebuah relasi, fungsi-fungsi ini dapat mencapai keseragaman dengan menegakkan aturan-aturan manipulasi kontrol data. Solusinya adalah dengan sentralisasi ataupun terdistribusi. Dua hal utama yang efisien untuk melakukan kontrol adalah definisi data dan penyimpanan aturan (situs pilihan) dan penegakan desain algoritma yang meminimalkan biaya komunikasi. Masalahnya adalah sulit, karena peningkatan fungsi (dan umum) cenderung meningkatkan komunikasi situs. Solusi untuk semantik data kontrol terdistribusi adalah eksistensi dari sentralisasi solusi. Masalahnya adalah sederhana jika aturan kontrol sepenuhnya direplikasi di semua situs dan sulit jika situs otonomi dipatenkan. Selain itu, khusus optimasi dapat dilakukan untuk meminimalkan biaya kontrol data tetapi dengan tambahan overhead seperti pengelolaan data snapshot. Dengan demikian, spesifikasi kontrol data terdistribusi harus disertakan pada desain database sehingga biaya kontrol update untuk programprogram ini juga dipertimbangkan[7].

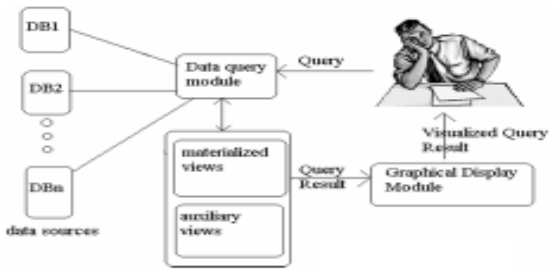

Gambar 3. Data Visualization dengan materialized and auxiliary views 
1. Penelitian ini dilakukan oleh Allison L.Powell James C.dkk,Perancis Departemen Ilmu Komputer Universitas Virginia, berjudul berjudul "The Impact of Database Selection on Distributed Searching”. Penelitian ini menjelaskan bahwa distributed searching terdiri dari 3 bagian yaitu database selection, query processing, dan results merging. Cukup beberapa database yang dijadikan database seleksi (tidak semuanya) dan performa akan meningkat cukup signifikan. Bila seleksi database dilakukan dengan baik, pencarian secara distributed akan berkinerja lebih baik dibandingkan pencarian secara sentralisasi. Pencarian database juga ditambahkan proses seleksi dan ranking sehingga secara potensial meningkatkan efektifitas pencarian data[8].

2. Penelitian ini dilakukan oleh Shadi Aljawarneh, Faisal Alkhateeb and Eslam Al Maghayreh yang berjudul "A Semantic Data Validation Service for Web Applications" dari Universitas Yarmouk. Penelitian ini menjelaskan bahwa Sebuah validasi Input bisa menjadi masalah kritis. menyebabkan kegagalan dalam perangkat lunak dan juga dapat mematahkan keamanan pada aplikasi web seperti akses tidak sah ke data. Sekarang, diperkirakan aplikasi web kerentanan (seperti XSS atau SQL injection) selama lebih dari dua pertiga dari keamanan web melaporkan kerentanan. Solusi untuk mencegah nya validasi baru layanan data yang didasarkan pada Web semantik Technologies, telah dirancang dan dilaksanakan untuk mencegah kerentanan keamanan web di aplikasi tingkat dan untuk mengamankan sistem web bahkan jika modul input validasi yang dilewati akan melewati beberapa eksekusi. Dengan demikian Dalam keamanan aplikasi web, validasi data adalah proses untuk memastikan bahwa aplikasi web beroperasi pada bersih, data yang benar dan berguna .Menggunakan aturan validasi yang memeriksa kebenaran, kebermaknaan, dan keamanan data yang masukan ke sistem berbasis web [9].

3. Penelitian yang dilakukan oleh Hamidah Ibrahim, "Deriving Global Integritas Dan Local Rules For Distributed Database”. Fakultas Ilmu Komputer dan Teknologi Informasi Universitas Putra Malaysia, 43400 UPM Serdang. Ibrahim mengatakan bahwa tujuan terpenting didalam database sistem adalah menjamin konsistensi data, yang berarti bahwa data yang terdapat dalam database harus baik dan akurat. Didalam pelaksanaannya untuk menjaga konsistensi perubahan data sangat sulit, khususnya untuk didistribusikan dalam database. Dalam tulisan ini, menjelaskan sebuah algoritma penegakan aturan berdasarkan mekanisme 
untuk didistribusikan database yang bertujuan meminimalisir jumlah data yang harus ditransfer atau diakses diseluruh jaringan yang menjaga konsistensi dari database di satu situs, yaitu di situs mana pembaruan perlu dilakukan. Teknik ini disebut sebagai tes integritas generasi, yang berasal dari lokal dan global integritas, dan aturan yang telah efektif dapat mengurangi biaya kendala dalam memeriksa suatu data yang telah didistribusikan dalam lingkungan. Didalam penelitian ini telah berhasil menghasilkan sebuah sistem sentralistik yang besar dengan tingkat kehandalan yang tinggi untuk integritas data [10].

4. Penelitian ini dilakukan oleh Untung Rahardja dan Shakinah Badar dari Perguruan Tinggi Raharja Indonesia yang berjudul "Penerapan metode Data Mart Query (DMQ) dalam Distributed Database System"tahun 2009. Penelitian ini menjelaskan Distributed database memiliki banyak keunggulan terlebih untuk struktur organisasi saat ini. Namun, karena banyaknya database yang tersebar dan jumlah data yang banyak dan terus meningkat didalam suatu organisasi maupun perusahaan. Jika suatu database memiliki sejumlah data yang tersimpan dengan banyak query dan tabel, suatu permintaan mengakibatkan proses pencarian data atau source data menjadi lambat. Selain itu banyaknya user yang dapat mengakses suatu tampilan web atau Web display suatu sistem informasi juga menjadi lambat. Dengan adanya Data Mart Query $(D M Q)$ merupakan metode yang tepat untuk mempercepat waktu proses pada suatu sistem informasi dengan database yang terdistribusi. DMQ ini digunakan untuk menghindari penggunaan Query majemuk. Dengan demikian DMQ akan mengorbankan besarnya kapasitas penyimpanan data (space hard disk) untuk meningkatkan kecepatan (increase speed) dalam pengaksesan. Hal ini pun telah dibuktikan baik secara logik, secara grafik dengan perhitungan regresi linear dan korelasi linear dan juga melalui implementasi [11].

Dari sebelas literature review yang ada, telah banyak penelitian mengenai checkpointing, parallel database system, pembahasan component database system, juga mengenai security. Disamping itu juga ada pembahasan mengenai nested transaction, distributed searching, view management, fragment allocation, dan juga $D M Q$. Namun dapat disimpulkan pula bahwa belum ada peneliti yang secara khusus membahas atau mengatasi masalah perihal batasan keamanan data melalui proses write validation. 


\section{PEMECAHAN MASALAH}

Untuk mengatasi permasalahan seperti yang telah dijelaskan diatas, dapat dilakukan melalui penerapan metode Write Validation. Berikut merupakan 3 ciri khas dari Write Validation yang diterapkan pada proses tambah kelas Otomatisasi Online Jadwal Rencana Study (O-OJRS) :

1. Adanya proses validasi sebelum eksekusi dijalankan.

2. Jika salah satu syarat tidak terpenuhi, maka proses eksekusi dibatalkan.

3. Jika seluruh syarat terpenuhi, maka proses tambah kelas dapat dieksekusi. Untuk menangani masalah keamanan batasan data pada proses tambah kelas O-OJRS, diperlukan suatu proses validasi guna melakukan pengecekan terhadap seluruh status batasan data. Batasan-batasan yang digunakan pada proses tambah kelas O-OJRS yaitu sebagai berikut :

1. Sesuai dengan kurikulum.

2. Belum tercantum didaftar nilai sebagai matakuliah yang lulus, dan tidak sedang diambil pada KST semester aktif.

3. Mata kuliah prasyarat sudah lulus atau sedang diambil pada KST semester aktif.

4. Populasi mahasiswa belum melebihi batas quota kelas.

5. Tidak bentrok dengan KST.

Untuk batasan 1,2, dan 3, merupakan batasan yang sifatnya relatif tetap. Biasanya berubah minimal semester sekali. Sehingga tidak terlalu berpengaruhi walaupun pengecekan telah menggunakan metode Write Validation.

Lain halnya dengan metode 4 dan 5 , yang sifatnya terus menerus berubah diberbagai user dan client. Saat seorang mahasiswa A menyatakan OK akan menambahkan sebuah kelas pada KST nya, maka syarat 4 dan 5 ini yang penting untuk divalidasi. Benarkah kelas tersebut tidak bentrok dengan KSTnya? Dan benarkah populasi mahasiswa belum melebihi batas quota kelas? Apabila populasi mahasiswa tercatat 50/51. Itu memiliki arti bahwa populasinya telah terisi 50 mahasiswa, dari batas quota yaitu 51. Berarti hanya tersisa 1 mahasiswa lagi untuk mengisi kelas tersebut. Mahasiswa lain yaitu mahasiswa B melalui client lain dapat mengisi lebih dahulu populasi kelas tersebut, dan menggenapkan quotanya menjadi 51/51. Sehingga mahasiswa A dinyatakan ditolak, tidak dapat menambahkan kelas tersebut dikarenakan status quota penuh. Hal ini sesuai dengan point nomor [1] dan [2].

Lain halnya jika segala prasyarat terpenuhi, maka proses penambahan kelas baru dapat dieksekusi. Hal ini sesuai dengan point nomor [3]. 


\section{IMPLEMENTASI}

Penanganan masalah keamanan batasan data menggunakan metode Write Validation sudah diimplementasikan pada Perguruan Tinggi Raharja, yakni pada sistem informasi SIS O-OJRS (Otomatisasi Online Jadwal Rencana Studi). Students Information Services atau yang biasa disingkat SIS, merupakan sistem yang dikembangkan oleh Perguruan Tinggi Raharja dengan tujuan sebagai sistem pelayanan informasi kepada mahasiswa secara optimal. Pengembangan SIS juga merupakan akses publikasi bagi Perguruan Tinggi Raharja di bidang ilmu komputer dan dunia IT khususnya.

SIS sudah dikembangkan ke dalam beberapa versi, dimana masing-masing merupakan kelanjutan dari SIS versi sebelumnya. SIS O-OJRS (Otomatisasi Online Jadwal Rencana Studi) merupakan SIS versi ke-4.2. Sesuai namanya, SIS O-OJRS dibuat untuk kebutuhan batal tambah KST mahasiswa secara online.

Hasil akhir yang ingin dicapai dari SIS O-OJRS ini yaitu dihasilkanlah sebuah sistem yang secara flexibel melayani segala proses batal tambah KST mahasiswa secara online dan dapat dilakukan secara mandiri. Prosesnya terdiri dari tambah kelas, pindah kelas, dan hapus kelas. Karena itulah, untuk dapat meningkatkan pelayanan terhadap mahasiswa, diterapkanlah metode Write Validation ini.

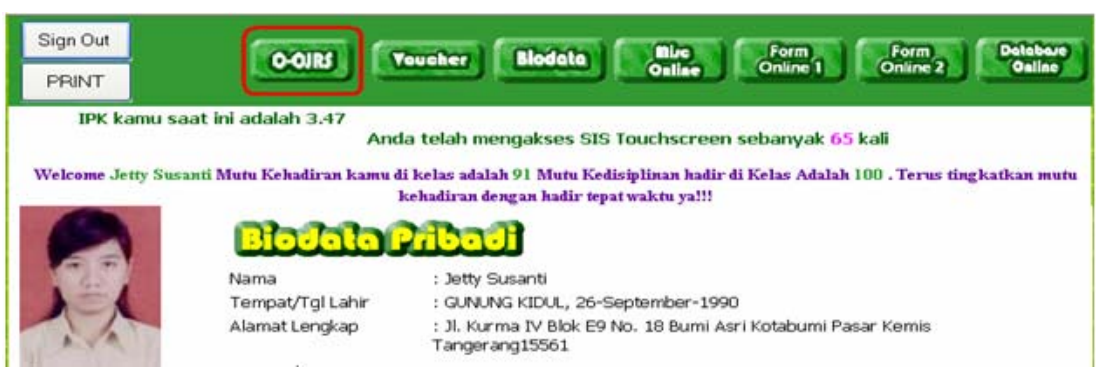

Gambar 4. Biodata Mahasiswa pada SIS

Gambar 4 diatas merupakan tampilan biodata mahasiswa. Dari halaman tersebut dapat diketahui segala informasi mengenai seorang mahasiwa, baik mengenai data pribadinya maupun mengenai data akademiknya. Untuk melakukan batal tambah KST, silahkan masuk pada menu O-OJRS. Akan ditampilkan tombol-tombol berbeda sesuai dengan status mahasiswa tersebut. Jika seorang mahasiswa dinyatakan belum membayar registrasi perkuliahan, maka pada menu O-OJRS hanya akan ditampilkan 1 tombol yaitu tombol JRS AKTIF. Namun jika seorang mahasiswa dinyatakan sudah registrasi, maka akan ada 3 tombol berbeda yang diklasifikasikan kembali berdasarkan status KST nya. Jika KST nya dinyatakan belum final, akan 
ditampilkan tombol JRS Aktif, tombol KST Aktif, dan tombol O-OJRS. Sementara jika mahasiswa tersebut dinyatakan sudah melakukan proses finalisasi pada KST, maka akan ditampilkan 3 tombol yang berbeda pula meliputi tombol JRS Aktif, tombol KSTF, dan tombol RBK. Untuk melakukan batal tambah online, dapat dilakukan dengan mengklik tombol O-OJRS. Berikut adalah tampilannya:

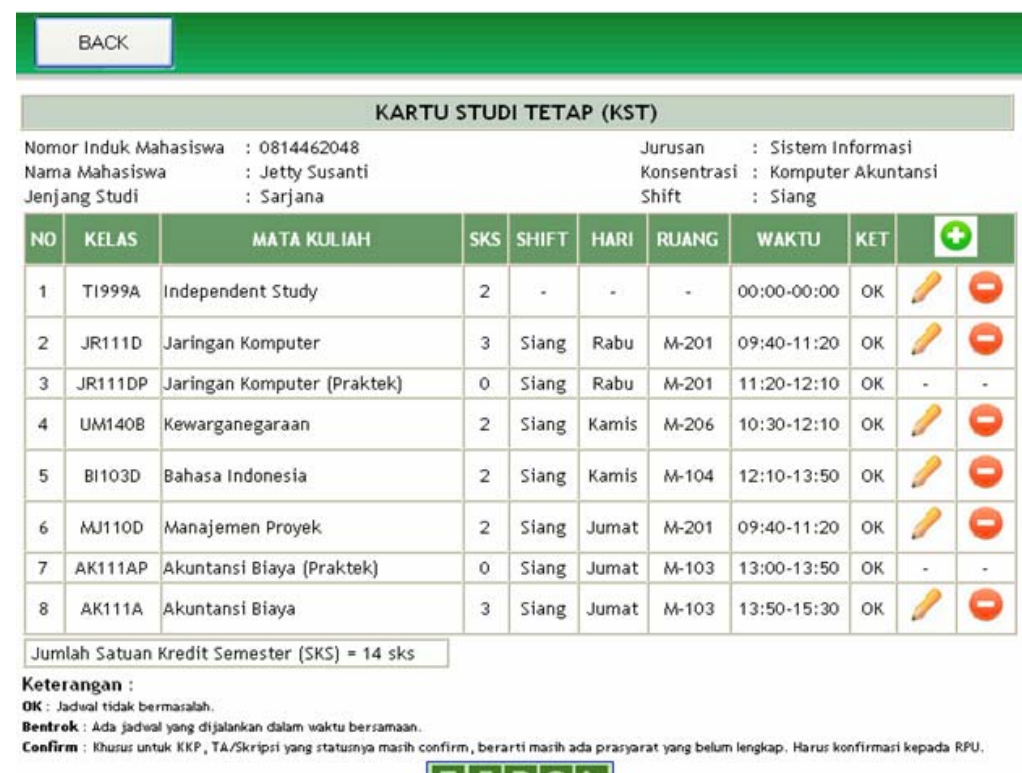

\section{F I I $\mid$ | $\mid$ |L}

Gambar 5. O-OJRS batal tambah

Metode write validation diterapkan pada proses tambah kelas O-OJRS. Untuk masuk kedalam fasilitas tambah kelas, silahkan klik di tombol plus (+ ) seperti pada gambar 5 diatas. Akan ditampilkan kelas-kelas yang telah diproses sebelumnya. Kelas-kelas tersebut telah memenuhi persyaratan sebagai berikut :

1. Sesuai dengan kurikulum.

2. Belum tercantum didaftar nilai sebagai matakuliah yang lulus, dan tidak sedang diambil pada KST semester aktif.

3. Mata kuliah prasyarat sudah lulus atau sedang diambil pada KST semester aktif.

4. Populasi mahasiswa belum melebihi batas quota kelas.

5. Tidak bentrok dengan KST. 
Berikut adalah daftar kelasnya:

BACK

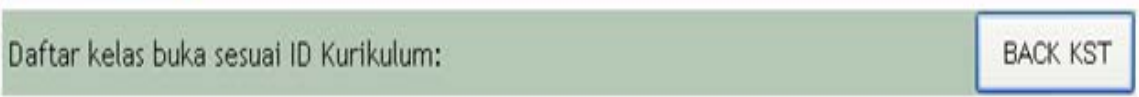

\begin{tabular}{|l|l|l|l|l|l|l|l|l|}
\hline NO & KODE KELAS & POPULASI & \multicolumn{1}{|c|}{ MATA KULIAH } & SKS & HARI & RUANG & MULAI & AKHIR \\
\hline 1 & SI131C & $49 / 50$ & Sistem Operasi & 3 & Senin & M-304 & $14: 40$ & $16: 20$ \\
\hline 2 & SI131F & $47 / 50$ & Sistem Operasi & 3 & Selasa & M-304 & $11: 20$ & $13: 00$ \\
\hline 3 & SI138B & $38 / 39$ & Sistem Basis Data & 3 & Rabu & M-201 & $13: 50$ & $15: 30$ \\
\hline 4 & SI138C & $38 / 39$ & Sistem Basis Data & 3 & Rabu & M-206 & $15: 30$ & $17: 10$ \\
\hline 5 & SI138BP & $38 / 39$ & Sistem Basis Data (Praktek) & 0 & Rabu & M-102 & $15: 30$ & $16: 20$ \\
\hline 6 & SI138CP & $38 / 39$ & Sistem Basis Data (Praktek) & 0 & Rabu & M-106 & $14: 40$ & $15: 30$ \\
\hline 7 & EK131A & $43 / 50$ & Matematika Ekonomi & 3 & Selasa & M-201 & $09: 40$ & $11: 20$ \\
\hline 8 & EK131AP & $43 / 50$ & Matematika Ekonomi (Praktek) & 0 & Selasa & M-201 & $11: 20$ & $12: 10$ \\
\hline 9 & MJ183B & $49 / 50$ & Rekayasa Piranti Lunak & 3 & Senin & M-206 & $09: 40$ & $11: 20$ \\
\hline 10 & MJ202B & $50 / 51$ & Komputer dan Masyarakat & 2 & Jumat & M-206 & $08: 00$ & $09: 40$ \\
\hline 11 & SI121B & $49 / 50$ & Sistem Informasi Manajemen & 3 & Senin & M-304 & $09: 40$ & $11: 20$ \\
\hline 12 & SI360A & $14 / 50$ & Sistem Penunjang Keputusan & 2 & Senin & M-207 & $11: 20$ & $13: 00$ \\
\hline 13 & MJ200B & $50 / 52$ & Etika Profesi & 2 & Selasa & M-206 & $13: 50$ & $15: 30$ \\
\hline 14 & MJ201F & $28 / 50$ & Kecakapan Antar Personal & 2 & Sabtu & M-206 & $12: 10$ & $13: 50$ \\
\hline
\end{tabular}

Gambar 6. Daftar kelas buka sesuai ID kurikulum pada O-OJRS tambah kelas

Pada gambar 6 diatas dijelaskan bahwa salah satu kelas yaitu SI131C memenuhi 5 persyaratan. Dinyatakan bahwa populasinya 49/50, artinya yaitu telah terisi 49 mahasiswa dari quota 50 mahasiswa. Yang berarti hanya dapat diisi oleh 
satu mahasiswa lagi. Jika ternyata mahasiswa atas nama Jetty ini berpikir terlalu lama, dan bingung ingin menambahkan kelas yang mana. Sementara ada mahasiswa lain dengan menggunakan client lain melakukan tambah kelas pada kelas SI131C, sehingga genap populasinya memenuhi quota menjadi 50/50. Maka saat Jetty melakukan tambah kelas pada kelas SI131C, sistem akan melakukan pengecekkan untuk 5 kriteria diatas.

Syarat 1 dan 3 sudah pasti LULUS, karena data kurikulum 90\% merupakan data statik yang hanya berubah pada kondisi tertentu. Syarat 2 pun sudah pasti LULUS, karena sifatnya yang semi statik. Perubahan datanya hanya terjadi satu semester sekali yaitu pada saat dikeluarkannya KHS oleh pihak manajemen. Sementara untuk syarat ke-4, yaitu mengenai quota. Syarat ini yang sifatnya sangat dinamik, dan terus berubah dalam hitungan detik. Setiap user mempunyai hak untuk dapat melakukan perubahan nilai populasi kelas melalui berbagai client, seperti gambaran kasus batal tambah diatas. Untuk itu, pada kasus batal tambah jetty diatas dinyatakan ditolak, dikarenakan populasi kelasnya sudah sama dengan nilai quota kelasnya, dan proses akan dikembalikan pada tampilan gambar 5 .

Syarat ke-5 yaitu mengenai bentrok. Sama halnya dengan syarat ke-4, syarat ke-5 ini sifatnya dinamik. Untuk itu perlu dilakukan validasi bahwa kelas yang dipilih statusnya tidak bentrok dengan jadwal KST yang ada. Jika ditemukan jadwal bentrok, maka proses akan di stop, dan akan dikembalikan pada tampilan gambar 5. Namun jika $0 \%$ bentrok, maka proses akan dieksekusi pada tahap selanjutnya.

a. Algoritma

Var

Char nim,kode_mk;

Int kelas,shift;

Main()

\{

*/ untuk cek bentrok 
rs $=$ seleksi $*$ from tabel daftar kelas where nim=nim and kode_mk like kode_mk $\%$ and kelas $=$ kelas

while not rs.eof

rs2 = seleksi $*$ from tabel KST where nim=nim and waktunya = waktu pada rs

jika ditemukan jadwal bentrok

Back to KST.asp?nim=nim

end if

wend

rs $3=$ seleksi $*$ from tabel daftar kelas where kode_mk like kode_mk $\%$ and kelas $=$ kelas and jam $=1$

while not rs3.eof

jika right $($ kode_mk,1)="P" then

kk2=left(kode_mk,5)\& (kelas)\&"P"

else

kk2= left(kode_mk,5)\&(kelas)\&"P"

end if

*/ untuk populasi dan quota kelas

jika right(kode_mk,1) $\diamond$ "P" and kode_mk $<>$ "TI999" and

kode_mk<>"TA100" and kode_mk $<>$ "TA101" and

kode_mk $<>$ "KP100" then

rs4 $=$ seleksi $*$ from tabel populasi where kode_kelas=kk2

rs5 $=$ seleksi $*$ from tabel Quota where kode_kelas $=\mathrm{kk}$

If populasi pada rs $4>=$ Quota pada rs 5 then

end if

Back to KST.asp?nim=nim

end if

EXECUSI DIJALANKAN

Wend 


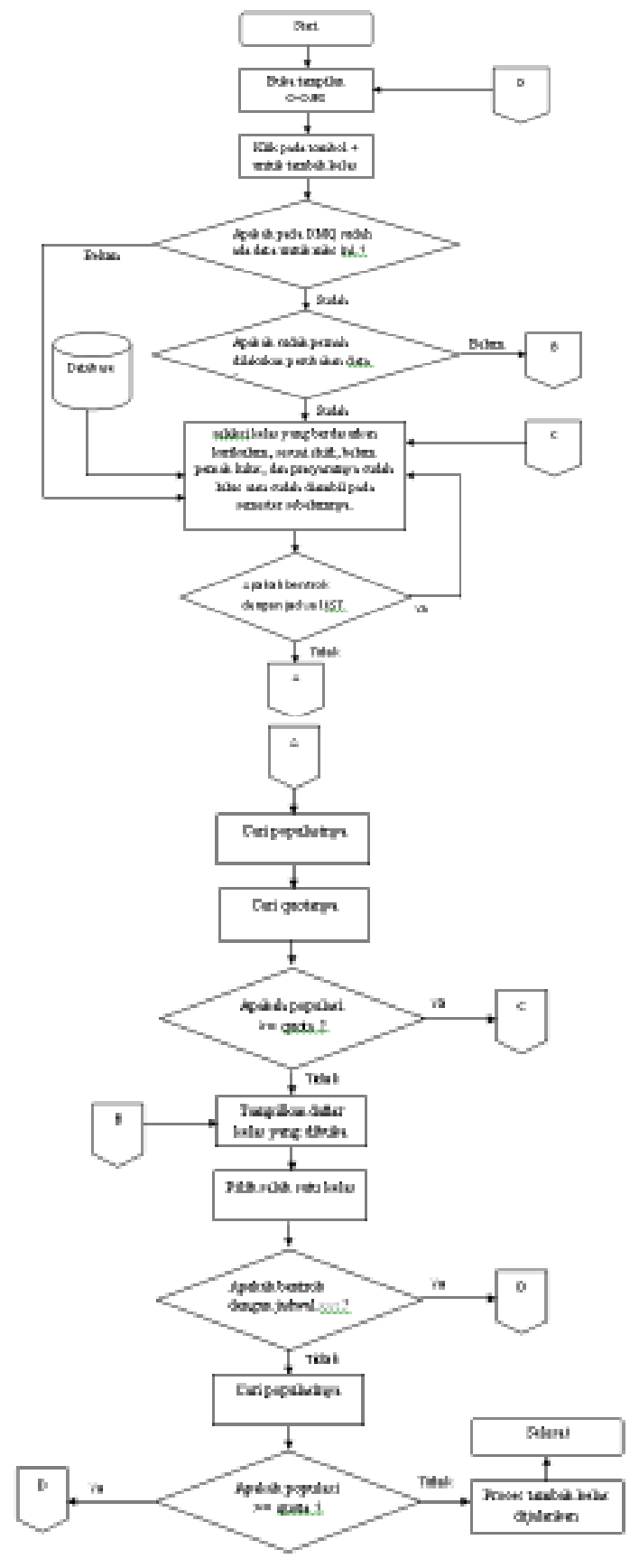

Gambar 7. Flowchart 
c. Source Code

1. Source code pada saat klik tombol + untuk melakukan tambah kelas

$<!$ \#include File="database.asp" $\rightarrow>$

$<\%$

server.ScriptTimeout $=4000$

nim=trim(request("nim"))

shft=trim(request("shft"))

'untuk cek apa pada DMQ sudah ada data untuk mahasiswa yang

bersangkutan

Sql_Cek2="select * from bt_tbh_kls where nim=""\&nim\&","

set rs_Cek2=conn.execute(Sq1_Cek2)

if not rs_Cek2.eof then

'bt_log_jml_proses untuk cek apakah telah dilakukan perubahan data

Sq1_proses5="select * from sysobjects where xtype='U' and Name='bt_log_jml_proses"”

set rs_proses5=conn.execute(Sq1_proses5)

if not rs_proses5.eof then

Sql_proses6="select Jml from bt_log_jml_proses where

nim="'\&nim\&"",

set rs_proses6=conn.execute(Sq1_proses6)

if rs_proses6.eof then

Response.Redirect(“daftar_kelas_tambah_id.asp?nim="\&nim)

else

if rs_proses6(“Jml”) $=0$ then

Response.Redirect(“daftar_kelas_tambah_id.asp?nim=”\&nim)

else nim="'\&nim\&"",

Sql_delete="delete from bt_tbh_kls where

set rs_delete=conn.execute(Sql_delete)

end if

end if

else

Response.Redirect(“daftar_kelas_tambah_id.asp?nim=”\&nim) 


\section{end if \\ end if}

'untuk seleksi kelas yang berdasarkan kurikulum, sesuai shift, belum pernah lulus, dan prasyaratnya sudah lulus atau sudah diambil pada semester sebelumnya

sqla="select distinct kode_mk from BT_12_8_SM where

shift="'\&shft\&"' and kode_mk not in (select kode_mk from

View_BT_KST2 where nim="'\&nim\&"') and kode_mk in (select kode_mk from view_mkul_id_kurikulum where nim="'\&nim\&"”) and kode_mk not in (select kode_mk from dmq_daftar_nilai where nim="'\&nim\&"” and nilai >=1.70) and kode_mk not in (select kode_mk from view_mkul_id_kurikulum where nim="'\&nim\&"' and Syarat $1 \diamond$ '-' and (Syarat1 not in (select kode_mk from dmq_daftar_nilai where nim="'\&nim\&"' and nilai >=1.70) or Syarat1 not in (select kode_mk from qsub_krs where nim="'\&nim\&"' and ta in (select ta from ao_aktif) and semester in (select semester from ao_aktif)) ) and (Syarat2 not in (select kode_mk from dmq_daftar_nilai where nim="'\&nim\&"' and nilai $>=1.70$ ) or Syarat1 not in (select kode_mk from qsub_krs where nim="'\&nim\&"' and ta in (select ta from ao_aktif) and semester in (select semester from ao_aktif))) ) and jam=1 order by kode_mk" set rsa $=$ conn.execute(sqla)

while not rsa.eof 'untuk cek bentrok sqlb="select distinct kode_mk,kelas from BT_12_8_SM where shift=""\&shft\&" and kode_mk="'\&trim(rsa("kode_mk"))\&" and jam=1 and right(No_Unit,3) not in (select right(No_Unit,3) from View_BT_KST2 where NIM="'\&nim\&"' and No_Unit is not null) order by kelas" set $\mathrm{rsb}=\mathrm{conn}$.execute(sqlb) while not rsb.eof sqlc="select kode_mk,kelas,no_unit from BT_12_8_SM where kode_mk="'\&trim(rsb(“kode_mk"))\&"P' and kelas="\&rsb("kelas")\&" and jam=1 and sks=0" set rsc=conn.execute (sqlc) if not rsc.eof then 
sqld="select right(No_Unit,3) from View_BT_KST2 where $\mathrm{NIM}=$ "'\&nim\&" and

$\operatorname{right}($ No_Unit,3)="'\&right(trim(rsc("No_Unit")),3)\&",", set rsd=conn.execute(sqld)

if rsd.eof then

sql="select * from BT_12_8_SM where kode_mk like

“"\&trim(rsb("kode_mk"))\&"\%” and

kelas="\&rsb("kelas")\&" and jam=1 order by sks desc"

set $r s=$ conn.execute(sql)

while not rs.eof

$$
\text { if rs("sks") }=0 \text { then }
$$

kk=left(trim(rs(“kode_mk")),5)\&kel(rs(“kelas”))\&”P”

else

kk=trim(rs(“kode_mk"))\&kel(rs(“kelas")) end if

sql_kurikulum="select semester from master_data_kurikulum where

id_kurkulum="'\&trim(rs_id_kunkulum('id_kurkulum"))\&" and

kode_mk=""\&left(trim(rs("kode_mk")),5)\&"",

setrs_kurikulum=conn.execute(sql_kurikulum)

sq12="select * from BT_12_8_SM where

kode_mk="'\&rs("kode_mk")\&"” and

kelas="'\&rs("kelas")\&" and jam=2"

set rs2=conn.execute(sq12)

'untuk cek populasi mahasiswa

kode_kelas=""\&kk\&","

sq13="select * from BT_14_1 where

set rs3=conn .execute(sql3)

JumKelas $=1$

Sq14="select * from View_BT_KST2 where

$\mathrm{NIM=" \& nim \& ""} \mathrm{and} \mathrm{Hari="" \& rs("Hari") \& "”}$

and

Mulai="'\&cdate(hour(rs('Mulai'))\&":'\&minute(rs("Mulai'))

\&":"\&second(rs(“"Mulai")))\&"'order by

Kode_MK,Jam" 


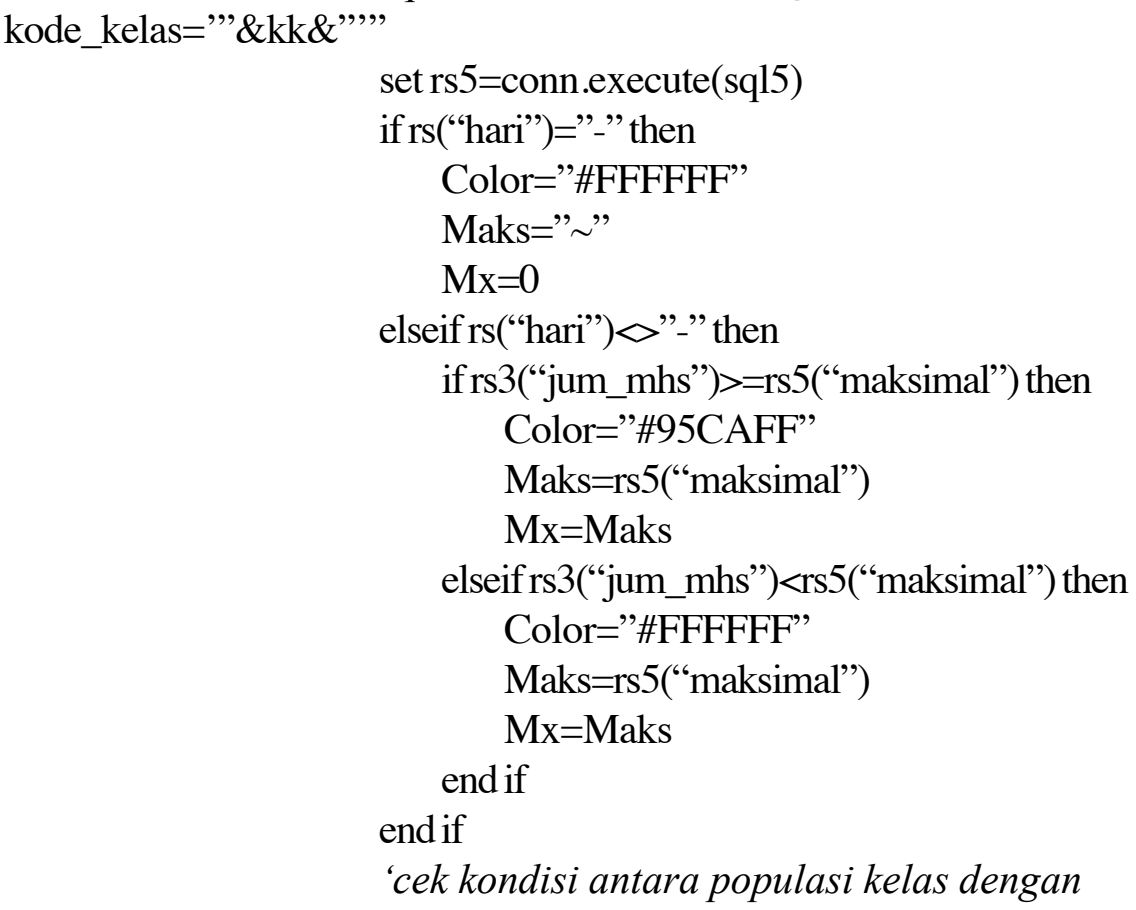

set rs5=conn.execute(sq15)

rs("hari")="-"'then

Color="\#FFFFFF"

Maks=",

if rs("hari") $\diamond$ "-" then

3("jum mhs") $>=$ rs5("maksimal") then

Color="\#95CAFF"

Maks=rs5("maksimal")

set rs4=conn.execute(Sq14)

While not rs4.eof

If not rs4.eof then

JumKelas=JumKelas +1

end if

rs4.movenext

wend

'untuk cek quota kelas

sq15="select * from CT_Quota where

quota

if rs3(“jum_mhs") $<$ Mx then

Sql_MK="select Mata_Kuliah from

Mata_Kuliah where

Kode=" \&trim(rs("kode_mk"))\&"",

set rs_MK=conn.execute(Sql_MK)

if rs("hari")="-" then

Color2="\#FF8A8A"

$\mathrm{T}=$ "Confirm"

elseif rs("hari") $<>$ "-" then

If JumKelas $>1$ then 


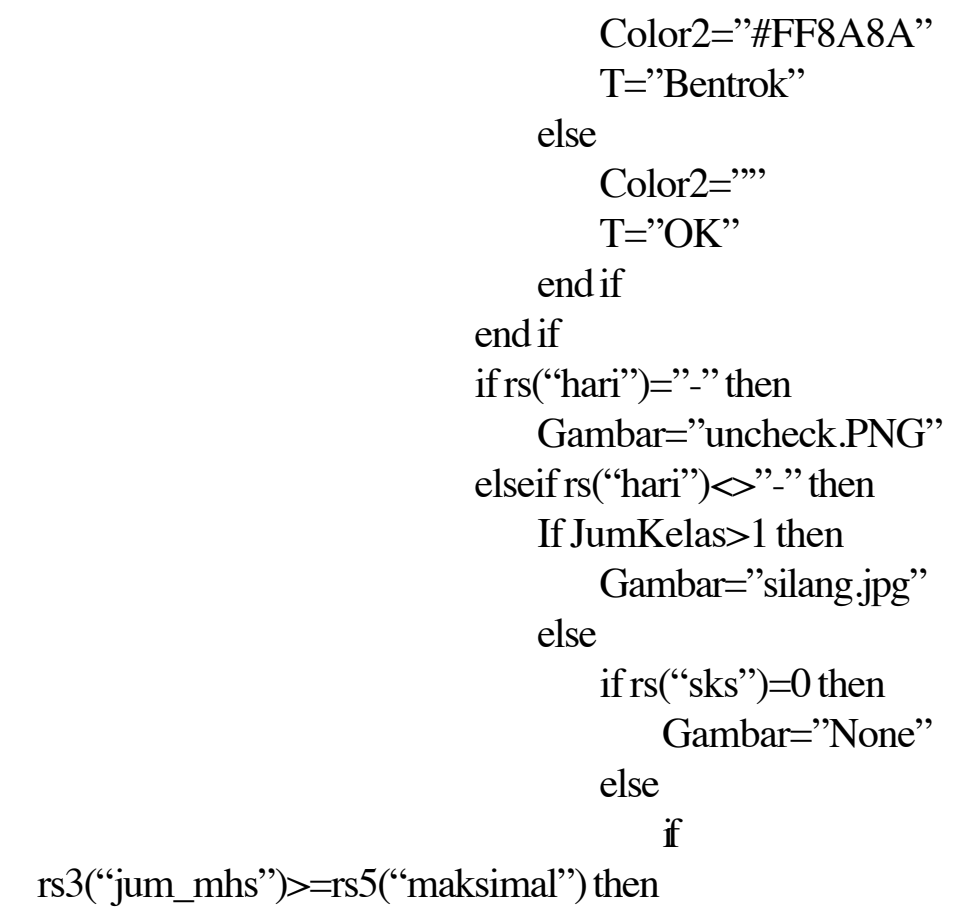

Color2="\#FF8A8A"

$\mathrm{T}=$ "Bentrok"

$\mathrm{T}=$ "OK"

end if

end if

f rs("hari")="-" then

-" then

If JumKelas $>1$ then

se

f rs("sks") $=0$ then

else

Gambar="silang.jpg" elseif

rs3(“jum_mhs") $\diamond$ rs5(“"maksimal”) then

$$
\begin{aligned}
& \text { Gambar="uncheck.PNG" } \\
& \text { end if } \\
& \text { endif } \\
& \text { end if } \\
& \text { endif } \\
& \text { Sql_insert="insert into }
\end{aligned}
$$

bt_tbh_kls(NIM,Kode_MK,Kelas,Kode_Kelas,Jml_Mh

s,Quota,Mata_Kuliah,Sks,Hari,Ruang,Mulai,Akhir,Sem ester,Gambar,Warna_populasi)

values(“"\&nim\&",,"”\&trim(rs(“kode_mk"))\&,",,\&rs(“ke

las")\&",,"\&trim(kk)\&,",,\&rs3(“jum_mhs")\&",,"\&Maks

\&",,"'\&trim(rs_MK(“Mata_Kuliah"))\&,",,\&rs(“sks")\&" 
,"'\&trim(rs(“hari”))\&",,"'\&trim(rs(“ruang”))\&", ,"'\&rs(“"

Mulai")\&",,",\&rs2(“akhir")\&",,"\&rs_kurikulum(“semes ter")\&","'\&trim(Gambar)\&",,"'\&trim(Color)\&"”)," response.write(Sql_insert\&"<br>") set rs_insert=conn.execute(Sql_insert) end if

rs.movenext

wend

end if

end if

rsb.movenext

wend

rsa.movenext

wend

$\%>$

2. Source code tampilan daftar kelas yang dibuka

$<!$ \#include File="database.asp" $\rightarrow>$

$<\%$

server.ScriptTimeout $=4000$

nim=trim(request("nim"))

'cek jumlah sks

jum_sk=0

Sql_sks="select distinct * from View_BT_KST2 where nim="'\&nim\&"" and jam $=1$ and sks $<>0 "$

set rs_sks=conn.execute(Sql_sks)

while not rs_sks.eof

jum_sk=int(jum_sk)+int(rs_sks(“'sks"))

rs_sks.movenext

wend

if jum_sk=18 then

Sql="select TOP $20 *$ from bt_tbh_kls where nim="'\&nim\&"' and sks $=2$ order by semester,kode_mk,kelas,sks desc" set rs=conn.execute $(\mathrm{Sql})$

else 
Sql="select TOP $20 *$ from bt_tbh_kls where nim="'\&nim\&"' order by semester,kode_mk,kelas,sks desc"

set rs=conn.execute(Sql)

end if

$\%>$

3. Source saat dipilih salah satu kelas pada daftar kelas yang dibuka

$<!$ \#include File="database.asp" $\rightarrow>$

$<\%$

nim=trim(request.QueryString("nim"))

mk2=trim(request.QueryString(“kode_mk2”))

kelas2=trim(request.QueryString("kelas2”))

ip=trim(request.ServerVariables(“REMOTE_ADDR”))

'bentrok

Sql_cek3="select distinct * from bt_12_8_sm where kode_mk like

"“\&mk2\&"\%" and kelas=""\&kelas2\&"",

set rs_cek3=conn.execute(Sq1_cek3)

while not rs_cek3.eof

Sql_cek4="select* from view_bt_kst2 where nim=""\&nim\&"" and right(No_Unit,3)="'\&right(trim(rs_cek3("No_Unit")),3)\&","

set rs_cek4=conn.execute(Sql_cek4)

If not rs_cek4.eof then end if

response.Redirect("kst.asp?nim="\&nim)

rs_cek3.movenext

wend

'looping kelas jika ada kelas praktikumnya

Sql_kelas1="select * from BT_12_8_sm where kode_mk like

"“\&mk2\&"\%" and kelas="'\&kelas2\&"” and jam=1"

set rs_kelas1=conn.execute(Sq1_kelas1)

while not rs_kelas1.eof

'kode kelas

if right(trim(rs_kelas1(“kode_mk")),1)="P" then

kk2=left(trim(rs_kelas1(“kode_mk")),5)\&kel(kelas2)\&"P"

else

kk2=trim(rs_kelas1(“kode_mk”))\&kel(kelas2) 
end if

'cek jumlah sks

If right(trim(rs_kelas1(“kode_mk")),1) $\diamond$ "P” then

$\mathrm{sk}=0$

Sql_sks="select distinct $*$ from View_BT_KST2 where

nim=" \&nim\&" and jam=1 and sks $\diamond 0$ "

set rs_sks=conn.execute(Sql_sks)

while not rs_sks.eof

sk=int(sk)+int(rs_sks(“"sks"))

rs_sks.movenext

wend

jum_sks_new=int(sk)+int(rs_kelas1(“"sks"))

If int(jum_sks_new) $>20$ then

response.Redirect("kst.asp?nim="\&nim)

end if

end if

'cek jumlah mhs dan quota

If right(trim(rs_kelas1(“kode_mk")),1) $\diamond$ "P” and

trim(rs_kelas1("kode_mk")) $\diamond " T I 999 "$ and

trim(rs_kelas1("kode_mk")) $\diamond$ "TA100" and

trim(rs_kelas1("kode_mk")) $\diamond " T A 101 "$ and

trim(rs_kelas1("kode_mk")) $\diamond$ "KP100" then

Sql_cek="select * from BT_14_1 where

kode_kelas="'\&kk2\&"",

set rs_cek=conn.execute(Sql_cek)

Sql_cek2="select* from CT_Quota where

kode_kelas="'\&kk2\&"",

set rs_cek2=conn.execute(Sq1_cek2)

If int(rs_cek(“Jum_Mhs")) >=int(rs_cek2(“Maksimal")) then

response.Redirect("kst.asp?nim="\&nim)

end if

end if

'apa ada di KST

Sql_cek5="select * from view_bt_kst2 where nim="'\&nim\&"" and kode_mk="”\&trim(rs_kelas1(“kode_mk"))\&"”, 
set rs_cek5=conn.execute(Sql_cek5)

If not rs_cek5.eof then

response.Redirect("kst.asp?nim="\&nim)

end if

sqla="select * from BT_12_8_sm where kelas=""\&kelas2\&"" and

kode_mk="'\&trim(rs_kelas1(“kode_mk")) \&"” and jam=1"

set rsa $=$ conn.execute(sqla)

sqlb="select * from BT_12_8_sm where kelas=""\&kelas2\&"' and

kode_mk="”\&trim(rs_kelas1(“kode_mk"))\&"” and jam=2"

set $\mathrm{rsb}=$ conn.execute(sqlb)

if ucase(rsa("hari"))=ucase("senin") then

urut=1

elseif ucase(rsa(“hari”))=ucase("selasa”) then

urut $=2$

elseif ucase(rsa("hari”))=ucase("rabu”) then

urut $=3$

elseif ucase(rsa("hari”))=ucase("kamis") then urut $=4$

elseif ucase(rsa("hari”))=ucase("jumat") then urut $=5$

elseif ucase(rsa("hari”))=ucase(“sabtu”) then urut $=6$

end if

'update table KST

sql2a="insert into view_bt_kst2

(akhir,hari,jam,kelas,kode_mk,mulai,nim,ruang,shift,sks,urut,No_Unit)

values (“"\&rsa("akhir”)\&”, “"\&rsa("hari”)\&”, ,"\&rsa(“jam”)\&”,

"'\&rsa("kelas”)\&”, “"\&rsa(“kode_mk”)\&”, “"“\&rsa(“mulai”)\&”,,

““\&nim\&”, “"“\&rsa(“ruang”)\&”, “"“\&rsa(“shift”)\&”, "“\&rsa(“sks”)\&”,

"“\&urut\&", "“\&rsa("No_Unit")\&"”)"

set $\mathrm{rs} 2 \mathrm{a}=$ conn.execute(sql2a)

sql2b="insert into view_bt_kst2

(akhir,hari,jam,kelas,kode_mk,mulai,nim,ruang,shift,sks,urut,No_Unit)

values (“"\&rsb(“akhir”)\&”, ,“\&rsb("hari”)\&”, ,"\&rsb(“jam”)\&”,

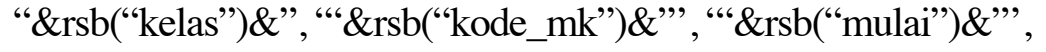


“"\&nim\&”, “"\&rsb(“ruang”)\&”, “"\&rsb(“shift”)\&”, “\&rsb(“sks”)\&”, “"\&urut\&", "“\&rsb(“No_Unit")\&”")"

set rs $2 b=$ conn.execute(sql2b)

'update table penghuni kelas

sq14="insert into BT_16_1 (kelas,kode_kelas,kode_mk,nim,shift) values (“"\&kelas2\&",,"'\&kk2\&",,"\&trim(rs_kelas1(“kode_mk"))\&",,

"'\&nim\&,","'\&rsa("shift")\&"”)"

set rs4=conn.execute(sq14)

'update table populasi

sq16="select jum_mhs from BT_14_1 where kode_kelas=""\&kk2\&"," set rs6=conn.execute(sql6)

jum2=rs6(“jum_mhs")+1

'update jum_mhs untuk kk2

sq113a="update BT_14_1 set jum_mhs="\&jum2\&" where

kode_kelas="'\&kk2\&","

conn.execute(sql13a)

'update tabel bentrok

Sq19="select * from View_BT_KST2 where NIM="'\&nim\&"' and

Jam=1"

set rs9=conn.execute(Sq19)

JumKelas $=1$

while not rs9.eof

sq110="select * from View_BT_KST2 where NIM=""\&nim\&"" and kode_MK<>"'\&rs9("Kode_MK")\&"” and Hari=""\&rs9("Hari”)\&"”, and Mulai=""\&cdate(hour(rs9("Mulai"))\&":"\&minute(rs9

("Mulai"))\&":"\&second(rs9(“Mulai")))\&",",

set rs $10=$ conn.execute $(\mathrm{sql} 10)$

while not rs 10.eof

if not rs10.eof then

JumKelas $=$ JumKelas +1

end if

rs10.movenext

wend

rs9.movenext 
wend

if jumkelas $>1$ then

sq111="insert into BT_16_1_1 (nim) values (“"\&nim\&”")"

set rs11=conn.execute(sq111)

end if

rs_kelas1.movenext

wend

'bt_log_jml_proses untuk menyatakan bahwa sudah adanya perubahan data dan DMQ tidak upate lagi

Sq1_proses1="select * from sysobjects where xtype='U' and

Name='bt_log_jml_proses"”

set rs_proses1=conn.execute(Sql_proses1)

if rs_proses1.eof then

Sql_create_proses="create table bt_log_jml_proses (Tgl datetime,

NIM varchar(10), Jml int)"

set rs_create_proses=conn.execute(Sql_create_proses)

Sql_proses2="'insert into bt_log_jml_proses (Tgl,NIM,Jml)

values(“"\&date()\&",,"'\&nim\&", 1)"

set rs_proses2=conn.execute(Sq1_proses2)

else

Sql_proses3="select Jml from bt_log_jml_proses where nim="'\&nim\&"",

set rs_proses3=conn.execute(Sq1_proses3)

if rs_proses3.eof then

Sql_proses4=”insert into bt_log_jml_proses (Tgl,NIM,Jml)

values(“"\&date()\&",,"\&nim\&", ,1)"

set rs_proses4=conn.execute(Sql_proses4)

else

Jml=int(rs_proses3(“Jml”))+1

Sql_proses4="update bt_log_jml_proses set Jml="\&Jml\&" where nim="'\&nim\&"",

set rs_proses4=conn.execute(Sql_proses4)

end if

end if

response.Redirect("kst.asp?nim="\&nim)

$\%>$ 


\section{KESIMPULAN}

Write Validation merupakan salah satu bagian penting pada proses pembuatan Otomatisasi Online Jadwal Rencana Study (O-OJRS). Cara kerjanya yang selektif mengontrol segala kondisi sebelum suatu proses dieksekusi, membuat data dan sistem menjadi aman walaupun diakses oleh berbagai user di berbagai client. Namun pengecekkan tersebut tetap memperhitungkan standar TWT (Tolerable Wait Time) agar tidak lebih dari 8,6 detik display data. Sehingga kenyaman pengguna terpenuhi, dan keamanan data pun tetap terjaga.

\section{DAFTAR PUSTAKA}

[1] Filipova Nadezhda dan Filipov Filcho. Development Of Database For Distributed Information Measurement And Control System University of Economics. Varna, Bul. Kniaz Boris I. 2008.

[2] Desmet Lieven, Jacobs Bart, Piessens Frank, Joosen Wouter. A Generic Architecture for Web Applications to Support Threat Analysis of Infrastructural Components. Eighth IFIP TC-6 TC-11 Conference on Communications and Multimedia Security (CMS). 2004.

[3] Lin. J. L., Dunham M. H. and Nascimento M. A. A Survey of Distributed Database Checkpointing. Texas: Department of computer science and engineering, Shoutern Methodist University. 1997.

[4] DeWitt. D.J., Gray.J. Parallel Database Systems: The Future of High Performance Database Processing. San Francisco: Computer Sciences Department, University of Wisconsin. 1992.

[5] Steven P Coy. Security Implications of the Choice of Distributed Database Management System Model: Relational Vs Object Oriented. University of Maryland. 2008.

[6] Stephane Gangarski, Claudia Leon, Hurbert Naacke, Marta Rukoz and Pablo Santini. Integrity Constraint Checking In Distributed Nested Transactions Over A Database Clustur. Laboratorie the Information Paris 6. University Pierre et Marie Curie 8 rue du Capitaine Scott, 75015, Paris. Centro de Computacion Paralela Y Distribuida, Universidad Central de Venezuela Apdo. 47002, Los Chaguaramos, 1041 A, Caracas, Venezuela. 2006.

[7] Stanchev Lubomir. Semantic Data Control In Distributed Database Environment. University of Waterloo. 2001. 
[8] Powell James C .Allison L, dkk. The Impact of Database Selection on Distributed Searching Perancis Departemen Ilmu Komputer Universitas Virginia.

[9] S. Aljawarneh, and F. Alkhateeb, A semantic web technology-based architecture for new server - side data validation in web applications, in Proceedings of International Conference on Information Technology,Amman Jordan, 2009, pp. 155-160.

[10] Ibrahim Hamidah. Deriving Global Integritas Dan Local Rules For Distributed Database Fakultas Ilmu Komputer dan Teknologi Informasi Universitas Putra Malaysia, 43400 UPM Serdang.

[11] Rahardja Untung and Badar Shakinah.Penerapan metode Data Mart Query (DMQ) dalam Distributed Database System. Perguruan Tinggi Raharja of Indonesian. 2009.

[12] W.B.Glisson and R. Welland, Web development evolution: The assimilation of web engineering security, in Proceedings of the Third Latin American Web Congres, Washington, DC, USA, IEEE Computer Society, 2005, pp. 4955.

[13] S. Sedaghat, J. Pieprzyk, and E. Vossough, On the web content integrity check boosts users' confidence, ACM Communication, vol. 45, no. 11, pp. 33-37, 2002.

[14] Y.Huang, S.Huang, T.Lin, and C. Tsai, Web application security assessment by fault injection and behavior monitoring, in Proceedings of the 12th international conference on World Wide Web, New York, NY, USA, ACM Press , 2003, pp. 148-159.

[15] Website Optimization (2010). Web Page Performance Thesis. Diakses pada tanggal 24 mei 2010 dari : http://www.websiteoptimization.com/speed/tweak/ web-page-performance-thesis/ 